\title{
A Technological Contingency Perspective on the Depth and Scope of International Outsourcing
}

Citation for published version (APA):

Mol, M. J., Pauwels, P. F. J., Matthyssens, P., \& Quintens, L. R. J. (2004). A Technological Contingency Perspective on the Depth and Scope of International Outsourcing. Journal of International Management, 10(2), 287-305. https://doi.org/10.1016/j.intman.2004.02.005

Document status and date:

Published: 01/01/2004

DOI:

10.1016/j.intman.2004.02.005

Document Version:

Publisher's PDF, also known as Version of record

\section{Please check the document version of this publication:}

- A submitted manuscript is the version of the article upon submission and before peer-review. There can be important differences between the submitted version and the official published version of record.

People interested in the research are advised to contact the author for the final version of the publication, or visit the DOI to the publisher's website.

- The final author version and the galley proof are versions of the publication after peer review.

- The final published version features the final layout of the paper including the volume, issue and page numbers.

Link to publication

\footnotetext{
General rights rights.

- You may freely distribute the URL identifying the publication in the public portal. please follow below link for the End User Agreement:

www.umlib.nl/taverne-license

Take down policy

If you believe that this document breaches copyright please contact us at:

repository@maastrichtuniversity.nl

providing details and we will investigate your claim.
}

Copyright and moral rights for the publications made accessible in the public portal are retained by the authors and/or other copyright owners and it is a condition of accessing publications that users recognise and abide by the legal requirements associated with these

- Users may download and print one copy of any publication from the public portal for the purpose of private study or research.

- You may not further distribute the material or use it for any profit-making activity or commercial gain

If the publication is distributed under the terms of Article $25 \mathrm{fa}$ of the Dutch Copyright Act, indicated by the "Taverne" license above, 


\title{
A technological contingency perspective on the depth and scope of international outsourcing
}

\author{
Michael J. Mol ${ }^{\mathrm{a}, *}$, Pieter Pauwels ${ }^{\mathrm{b}}$, \\ Paul Matthyssens ${ }^{\mathrm{c}, \mathrm{d}}$, Lieven Quintens ${ }^{\mathrm{c}}$
}

\author{
${ }^{\text {a }}$ The Business School, University of Reading, P.O. Box 218, Reading, RG6 6AA, UK \\ ${ }^{\mathrm{b}}$ Faculty of Economics and Business Administration, Maastricht University, The Netherlands \\ ${ }^{\mathrm{c}}$ Faculty of Applied Economic Sciences, Limburg University Center, Belgium \\ ${ }^{\mathrm{d}}$ Rotterdam School of Management, Erasmus University Rotterdam, The Netherlands
}

\begin{abstract}
In this study, we present and test a technological contingency perspective on two dimensions of international outsourcing: depth and scope. The depth of international outsourcing refers to the ratio of foreign to total outsourcing. The scope of international outsourcing captures the degree of psychic dispersion between the country of operations and the countries a firm is outsourcing from. Using multiple regression analysis on a sample of 189 firms in the Netherlands, the effect of five technological contingency factors is measured: product innovation, technological and volume uncertainties, asset specificity, and the integration of the outsourcing function. A most interesting finding is that technological uncertainty and the degree of product innovation turn out to be both positively associated with a high scope-low depth type of international outsourcing and negatively associated with a low scope-high depth type of international outsourcing. The findings create a platform for a two-dimensional typology, which provides an explanatory logic for the expansion and development path of international outsourcing.

(C) 2004 Elsevier Inc. All rights reserved.
\end{abstract}

Keywords: International outsourcing; Technological contingency; International expansion

\section{Introduction}

International outsourcing has been identified as one of the major trends both in purchasing management (Trent and Monczka, 1998; Carter et al., 2000) and international business (Kotabe, 1998). Through the expansion of their supply base across geographical

* Corresponding author. Tel.: +44-118-378-7941; fax: +44-118-378-6229.

E-mail address: m.mol@reading.ac.uk (M.J. Mol). 
borders, firms open up a wider potential supply range that enables them to select worldclass suppliers and effectively minimize the cost of supplies (Bryce and Useem, 1998). Notwithstanding its potential strategic and financial impact, international outsourcing remains a somewhat neglected phenomenon in the empirical purchasing and supply chain literature (Petersen et al., 2000) and has often been considered an off-center topic in the international business literature (Murray et al., 1995; Buckley, 2002). For instance, no more than 10 articles could be retrieved from the Journal of International Business Studies archive (1970-2002) that specifically dealt with international (out)sourcing or organizational purchasing across borders. If available, empirical insight dates back to the late 1980s and early 1990s and is mostly exclusively focused on the international outsourcing behavior of U.S.-based firms. Research on outsourcing internationalization by European firms has been confined to case-based explorations of the structure and functions of particular outsourcing networks (e.g., Dubois, 1998; Ford, 1998). As a consequence, hardly any empirical evidence on international outsourcing strategies in Europe is available. As a consequence of the relatively poor coverage and theoretical isolation of international outsourcing, some fundamental questions on this phenomenon remain unanswered.

A prime question is whether international outsourcing is to be considered a reactive manifestation of a cost-minimizing strategic approach or rather a proactive valuemaximizing strategy. The former has been adopted as an implicit assumption in many earlier studies (e.g., Bailey et al., 2002). For the present study, we also include the latter perspective, which points at the critical role of international outsourcing in the strategic and technological prowess of firms (Kotabe, 1998; Petersen et al., 2000). Dunning (1993) has suggested that international outsourcing may be used most frequently for either very low tech or very high tech products but not much in the intermediate range. To the best of our knowledge, this suggested $U$ curve is still to be investigated empirically.

The present paper focuses on the effect of technological contingencies on international outsourcing. More specifically, we investigate the impact of product innovation, volume and technological uncertainties, asset specificity, and the integration of the outsourcing function on the degree of international outsourcing. A highly related but more dynamic issue is how these technological parameters influence the international expansion of outsourcing. Although the outsourcing internationalization process has been covered in earlier studies (e.g., Monczka and Trent, 1992; Monczka et al., 2002), the proposed expansion models have many times been embedded in an establishment chain or 'stages' perspective (Cavusgil, 1980; Reid, 1984). As a consequence, development models of international outsourcing may lack explanatory and predictive power over the factors that stimulate or obstruct interstage movement along the outsourcing internationalization path (Leonidou and Katsikeas, 1996). Therefore, a second aim of this paper is to investigate how the aforementioned technological parameters impact-i.e., stimulate, obstruct, or steer - the expansion path of international outsourcing.

The remainder of this paper is structured as follows. First, we present a twodimensional conceptualization of the degree of international outsourcing, the main dependent construct. Next, we focus on technological parameters that are potential drivers of international outsourcing. Perspectives on the relationships between international 
outsourcing and product innovation, volume and technological uncertainties, asset specificity, and the integration of the outsourcing function are converted into hypotheses. We then develop the measures and discuss the method of the empirical study. A presentation and discussion of the analytical results in the next two sections brings us to a typology of international outsourcing. This typology allows us to formulate preliminary propositions on the expansion and development path of international outsourcing. We finish the paper with a discussion of its limitations and an agenda for future research on international outsourcing.

\section{Depth and scope of international outsourcing}

The focus of this study is the location dimension of outsourcing, more particularly the degree of outsourcing outside a country of operations. We capture the degree of international outsourcing through two dimensions: depth and scope. At the firm level, depth is an indicator of the economic penetration of international outsourcing and has often been operationalized as a ratio of outsourcing abroad to total outsourcing (Birou and Fawcett, 1993; Kotabe and Omura, 1989; Mol et al., 2002; Servais and Møller Jensen, 2001; Swamidass and Kotabe, 1993). Intuitively, this single economic criterion seems to capture the degree of international sourcing at large. However, for many years, scholars have pled for a multidimensional conceptualization of internationalization (e.g., Welch and Luostarinen, 1988; Sullivan, 1994, 1996). Indeed, the depth dimension of international outsourcing focuses on the economic outcome of outsourcing solely, forgoing its dynamic and structural character. Therefore, we propose 'scope' as a second dimension of international outsourcing.

Following Sullivan (1994) and in analogy with the market expansion and diversification literature (e.g., Ayal and Zif, 1979; Olusoga, 1993), the scope dimension captures the degree of diversification of international outsourcing and is operationally defined as a measure of psychic dispersion. The rationale for this scope dimension builds upon the notion of psychic distance, a central construct in the organizational behavior theory of internationalization (Johanson and Vahlne, 1977; Hallén and Wiedersheim-Paul, 1989). The psychic distance between countries is the degree to which a firm in a focal country is uncertain of the characteristics of foreign (sourcing) markets. Elaborating the notion of bounded rationality (March and Simon, 1958), the main assumption is that firms are less likely to take up outsourcing relations with suppliers from countries that are perceived to be dissimilar (i.e., show high psychic distance, see Stöttinger and Schegelmilch, 1998). A higher psychic distance indicates a higher perceived cost-benefit ratio of a particular venture or, at least, increases ambiguity over expected costs and benefits of the outsourcing process to that particular region. Although it is presumed that psychic distance decreases when experience grows (Grisprud, 1990), the psychic distance at the outset of a new outsourcing venture indicates the maximal level of dissimilarity a firm has to deal with in terms of risk reduction and difficulty of knowledge internalization. The scope of outsourcing internationalization matters greatly for the managerial complexity of the international outsourcing process, as high scope implies higher learning costs on how to manage intercultural relations with multiple and far-away suppliers (Andersen and 
Buvik, 2001). Furthermore, it is operationally much more complex to manage a supplier network that encompasses such a wide range of countries.

In sum, a two-dimensional conceptualization of the degree of international outsourcing is proposed. The depth of international outsourcing captures the economic penetration of foreign outsourcing in a firm's total amount of outsourced activities. The scope of international outsourcing refers to the risk, ambiguity, and complexity of learning during the outsourcing internationalization process. This way, our conceptualization captures the inherently dynamic character of international outsourcing.

\section{A technological contingency perspective}

A limitation of some earlier studies on international outsourcing is that they did not take into account environmental factors that may impact upon the strategic role of international outsourcing in the framework of a firm's corporate strategy. More recent studies have illustrated that situational variables do have a significant moderating effect on the appropriateness of particular outsourcing strategies (e.g., Murray et al., 1995; Murray, 2001). The basic assumption of a contingency approach as presented hereafter is that the appropriateness of a certain degree of international outsourcing depends on relevant moderating context factors (Lawrence and Lorsch, 1967; Prescott, 1986). Various contingency variables may have a potential impact on the outsourcing strategy in general and on the degree of international outsourcing in particular. However, from a theoretical and empirical perspective, technological contingencies seem to outperform other potential variables in their impact on international outsourcing. The ongoing stream of research on strategic technology partnering illustrates and underpins the strategic role of outsourcing strategies in the context of technology-dominated industries and competition (e.g., Hagedoorn and Narula, 1996; Steensma and Corley, 2000; Steensma and Fairbank, 1999). Murray et al. (1995), among others, have illustrated empirically the significant impact of moderating factors such as product innovation, process innovation, and asset specificity.

Elaborating on the aforementioned stream of research, this study's technological contingency perspective relies upon four factors: product innovation, asset specificity, volume uncertainty, and technological uncertainty. The degree of product innovation is an internal technological parameter that captures the flow of ongoing innovative activity within the firm. Asset specificity complements the first parameter and captures a firm's stock of internalized technology and specialized assets in terms of specialized labor, manufacturing equipment, and production location. From an external perspective, volume and technology uncertainties represent the volatility of an industry, which is inherently related to the level of innovative behavior at the level of suppliers (Eisenhardt, 1989). Together, these four factors are used to capture the technological situation in which international outsourcing is developing. In addition to these technological parameters, the integration of the outsourcing function in the supply chain of the firm is focused upon. The rationale for including this variable is that a high degree of integration is a prerequisite for the strategic role of the outsourcing function in a firm that builds and competes on the basis of its (internalized) technological capabilities 
(Narasimhan and Carter, 1990; Kotabe, 1992). In the remainder of this section, the relationship between each of these contingency factors and the degree of international outsourcing is developed and translated into specific hypotheses.

\subsection{Product innovation}

Kotabe and Murray (1996) and Kotabe et al. (1998) suggest that the degree of product innovation has no significant impact on a firm's make-or-buy decisions. Nevertheless, we concur with Murray et al. (1995) that the degree of product innovation does have a relevant impact on the degree of international outsourcing. Under conditions of high product innovation activity, firms internalize more new technological knowledge than when the rate of product innovation is lower (Eisenhardt and Tabrizi, 1995). It has been argued that highly innovative firms intensify their global searching activity to obtain and combine knowledge from various specialized sources around the world (Doz et al., 2000). Therefore, it is expected that during periods of increased product innovation, a firm seeks innovative solutions outside the current portfolio of suppliers. To obtain this new knowledge, the firm is willing to invest in new supplier relations and to incur economic and emotional costs to overcome the increased psychic distance it faces. As a consequence, we expect that a growing scope of international outsourcing is intertwined with increasing product innovation.

However, it is expected that this widening scope will be driven by the technological core of the product innovation process. To compensate for the risks, complexity, and (opportunity) costs of increased product innovation, a firm is expected to reduce its risk-seeking behavior for nonfocal inputs, which are expected to remain the bulk of its inputs. Ceteris paribus, we expect that increased product innovation activity reduces the depth of international outsourcing inasmuch as the larger quantities of international outsourcing are related to the aforementioned cost minimization argument. An innovative firm will source the bulk of its nonstrategic inputs from suppliers as close as possible to the country of operations. In sum, we forward the following hypotheses:

Hypothesis 1a: Product innovation is negatively associated with a firm's depth of foreign outsourcing.

Hypothesis 1b: Product innovation is positively associated with a firm's scope of foreign outsourcing.

\subsection{Asset specificity}

The more (technology-)specific a firm's production facilities are, the more they embed the firm's technological competitive advantages. Yet, high asset specificity provides limited freedom with respect to labor, equipment, and location choices. Various authors have investigated the importance of asset specificity in international outsourcing contexts (Andersen and Buvik, 2001). Murray et al. (1995) and Kotabe and Murray (1996) found a positive relation between the degree of asset specificity and the extent of 
the internal outsourcing of components in multinational firms. Given their strategic importance, firms want to optimize the efficiency and the effectiveness of these assets. Due to their technology-specific character, firms may need to rely on very specialized suppliers to ensure an optimal yield of these assets (Andersen and Buvik, 2001). Inasmuch as the redeployment value of these assets is limited (sunk costs), firms may want to incur relatively high outsourcing costs and risks to assure optimal input. As a consequence, we hypothesize that, ceteris paribus, asset specificity has a positive impact on the scope of international outsourcing. Although this scope incurs costs in terms of increased psychic distance, firms do not compensate for these costs by reducing the depth of their international sourcing, as in the case of product innovation. A suboptimal depth would reduce the yield of the assets. Assuming the benefit of having a proper supplier to be larger than the cost of the increasing depth, we hypothesize a positive impact of asset specificity on the depth of international sourcing. In general, high asset specificity will force firms to look for highly specialized supply sources, wherever in the world, particularly if the size and scope of the local supply base is limited.

Hypothesis 2a: Asset specificity is positively associated with a firm's depth of foreign outsourcing.

Hypothesis 2b: Asset specificity is positively associated with a firm's scope of foreign outsourcing.

\subsection{External factors: volume and technological uncertainties}

Intuitively, one would expect that increased uncertainty over (technological) evolutions in the market impacts the international sourcing strategy of a firm. Yet, empirical validation and theoretical explanation of this relationship remains a fallow field (Deavers, 1997). Following Walker and Weber (1984), we focus on technological uncertainty and volume uncertainty. Volume uncertainty refers to the fluctuations and uncertain estimates of input volumes, while technological uncertainty denotes general changes in specifications and frequent technological improvements and changes.

Increasing complexity and decreasing reliability of supply chains are expected to affect both the scope and depth of outsourcing internationalization (Levy, 1995). To compensate for increasing input volume uncertainty, firms are expected to prefer close-to-home suppliers as well as to reduce their portfolio of suppliers, respectively, to increase control and negotiation power. When volume uncertainty is high, firms will tend to simplify and condense their supply chains as much as possible by choosing more local suppliers and by limiting the number of countries they source from. Therefore, we state that

Hypothesis 3a: Volume uncertainty is negatively associated with a firm's depth of foreign outsourcing.

Hypothesis 3b: Volume uncertainty is negatively associated with a firm's scope of foreign outsourcing. 
When technological uncertainty is considered high, firms are expected to react in two ways. On one hand, a firm wants to reduce this uncertainty by seeking best-in-class suppliers all over the world. To a certain extent, the desire to decrease technological uncertainty in cooperation with a world-class supplier from a remote country overcompensates the psychic distance to that particular country. On the other hand, increased complexity, ambiguity, and perceived risk resulting from the cooperation with world-class suppliers is offset by reducing risk-seeking outsourcing behavior in nonstrategic outsourcing. A firm will cluster these nonstrategic inputs - yet in most cases, the bulk of inputs - as close as possible to the site of operations, concentrated in a more controllable number of suppliers. Hence, we put forward the following hypotheses:

Hypothesis 4a: Technological uncertainty is negatively associated with a firm's depth of foreign outsourcing.

Hypothesis 4b: Technological uncertainty is positively associated with a firm's scope of foreign outsourcing.

\subsection{Integration of outsourcing function}

Kotabe (1992) stressed that global outsourcing operates at the interfaces of the marketing, $\mathrm{R}$ and $\mathrm{D}$, and production functions. In his point of view, these functions operate best when there is sufficient coordination between them. Global outsourcing, even when it cuts production costs, should not be applied if it undermines the long-term technological capabilities of the firm. This implies that close cooperation inside the firm will be needed to facilitate foreign outsourcing. Yet, the integration of the purchasing department with other departments in the company is a seldom-used variable. In their conceptual paper, Narasimhan and Carter (1990) describe the advantages and disadvantages of different organization structures for international outsourcing. They suggest that when the purchasing department is well integrated with other parts of the firm and both formal and informal interdepartmental communication exists, more information is passed through, and knowledge creation is enhanced. Moreover, when values on internationalization are shared within a company, more support is given towards international activities. This increasing support implies that refusals for international pilot sourcing projects will be less frequent, hereby increasing the scope of foreign outsourcing more rapidly. Besides the scope, the depth will also be positively influenced. More integration leads to better specifications of inputs, facilitating explicit ordering with foreign suppliers, lowering the costs of communication and thus increasing the total amount of inputs sourced abroad. Therefore,

Hypothesis 5a: The extent of integration of the purchasing department with other departments is positively associated with a firm's depth of foreign outsourcing.

Hypothesis 5b: The extent of integration of the purchasing department with other departments is positively associated with a firm's scope of foreign outsourcing. 


\section{Method and measures}

A mail survey on international outsourcing strategy was sent to 787 managers of medium-sized and large manufacturing firms in the Netherlands in late 2000 and early 2001. The Netherlands makes a good case for a study on international outsourcing because it is a small and open economy with substantial foreign investments in various manufacturing industries as well as various well-established local firms with substantial international experience. Thus, international outsourcing can be expected to be relatively prominent in the Netherlands. The surveyed firms were manufacturing members of NEVI, the Dutch equivalent of the NAPM.

The survey was pretested through several interviews. Two rounds of mail surveys were sent out following the regular procedures (Dillman, 1978). After those two rounds, close to 2000 telephone calls were executed to get in touch with respondents. There were several reasons for these calls. First, they helped increase the number of responses by encouraging potential respondents. Second, sometimes, it was the case that the person in question no longer worked for the firm but some other knowledgeable person was traced by telephone, usually the targeted person's successor. Third, for those firms that had not completed a survey, we could establish the reasons for not doing so. Thus, it was possible to analyze in some detail the reasons for nonresponse among a great majority of the remaining firms in the sample. Groups of 19 (survey was never delivered), 67 (survey inappropriate for firm), and 30 (survey inappropriate for individual), or 116 firms can be dropped from the sample when calculating the effective response rate. A total valid response of 204 firms was obtained. If at least $80 \%$ of the survey was completed, a response was seen as valid. This implies the effective response rate for the survey is $204 / 671 \times 100 \%$, or $30.4 \%$, which is reasonably high. For this particular analysis, 189 firms had valid responses for all variables employed and responded upon early enough to be processed. Next, additional background information was obtained from Statistics Netherlands (CBS), through which we established that there was no nonresponse bias inasmuch as respondents and nonrespondents were not significantly different in terms of turnover, number of employees, extent of outsourcing, and profitability.

To measure the depth of international outsourcing (DEPTH), firms were asked to indicate the ratio of international sourced inputs to total inputs, with respect to their most important product. The question was: "Out of $100 \%$ of all the volume your firm sources externally, what percentage stems from the Netherlands, Belgium/Luxembourg, Denmark/ Finland/Norway/Sweden, Germany/Austria/Switzerland, France/Italy/Spain/Portugal, UK/ Ireland, Greece, Central and Eastern Europe, US/Canada/Australia, Japan, rest of Asia, and rest of world?"

The scope of international outsourcing (SCOPE) was operationalized by assigning the value 1 if a firm outsources from a certain block ( 0 if it does not) and then multiplying this by the psychic distance to that block. The psychic distance to a block is 0 for the Netherlands; 1 for Scandinavia; 2 for the Belgian, Germanic, UK and Ireland, other Anglo-Saxon, and Latin blocks; and 3 for CEE, Japan, the rest of Asia, and the rest of the world. Consequently, the scope of international outsourcing is calculated as: $\mathrm{SCOPE}=D_{1}+D_{2}+\ldots+D_{n}$, where $n$ is the number of countries the firm outsources 
from and $D$ is the psychic distance between the focal country and a foreign country in which external suppliers are located.

Through summing the values for all blocks, we obtain a score on SCOPE. For instance, a firm that only outsources from the Netherlands has a SCOPE of $1 \times 0=0$, while a firm that outsources from the Netherlands, Scandinavia, and Japan is assigned a value of $1 \times 0+1 \times 1+1 \times 3=4$. This measure reflects not only how many countries a firm is outsourcing to but also how remote (in psychic terms) these countries are to that firm.

The applied measures for the remaining variables are summarized in Table 1.

The degree of product innovation was used as an independent variable, using the measures of Murray et al. (1995). Here a Cronbach $\alpha$ of .80 was obtained using two out of three proposed items, inasmuch as those two measures generated the highest reliability. To measure volume and technological uncertainties, the scales proposed by Walker and Weber (1984) were used $(\alpha=0.59$ and $\alpha=0.56$, respectively). Unfortunately, both $\alpha$ s are reasonably low - a potential cause for concern. Asset specificity was measured using the criterion proposed by Murray et al. (1995).

At this point, we added two more variables to increase the internal validity of the study: firm size and degree of multinationality. Although they are not in the core of our study, both variables are generally accepted by the literature to have a positive impact on the degree of international outsourcing. Firm size was measured by the logged annual outsourcing budget. Larger firms will have size and knowledge advantages, which enable them to outsource

Table 1

Overview of variables and measures

\begin{tabular}{|c|c|c|}
\hline Variable & Label & Measurements \\
\hline Firm size & LOGPURBU & - Logarithm of yearly purchasing budget in monetary terms \\
\hline $\begin{array}{l}\text { Extent of purchasing } \\
\text { integration }\end{array}$ & PURINTEG & $\begin{array}{l}\text { - Integration with other functions: 'not at all', 'not really', } \\
\text { 'average', 'strongly', or 'very strongly' }\end{array}$ \\
\hline Asset specificity & ASSETSPE & $\begin{array}{l}\text { - When manufacturing nonstandardized components, the } \\
\text { level of specific assets or resources is }(0=\text { zero, } 5=\text { very high })\end{array}$ \\
\hline Volume uncertainty & VOLUNCER & $\begin{array}{l}\text { Expected volume fluctuations - the extent to which significant } \\
\text { fluctuations are expected in the daily or monthly volume } \\
\text { requirement for the component (Likert-type scale of } 1 \text { to 5) } \\
\text { - Uncertain volume estimates-the extent to which volume } \\
\text { estimates for the component are expected to be uncertain } \\
\text { (Likert-type scale of } 1 \text { to 5) }\end{array}$ \\
\hline Technological uncertainty & TECHUNCE & $\begin{array}{l}\text { - Changes in specifications - the frequency of expected changes } \\
\text { in specifications for the component (Likert-type scale of } 1 \text { to 5) } \\
\text { - Technological improvements - the probability of future } \\
\text { technological improvements of the component } \\
\text { (Likert-type scale of } 1 \text { to 5) }\end{array}$ \\
\hline Product innovation & PRODINNO & $\begin{array}{l}\text { - To your firm, the level of product innovation in the product } \\
\text { (i.e., the set of innovative ideas involved in the product) is } \\
(0=\text { zero, } 5=\text { very high }) \\
\text { - Relative to your competitors, the level of product } \\
\text { innovations in your product is }(1=\text { very low, } 5=\text { very high }) \\
\text { - The number of potential applications (or uses) of the } \\
\text { product innovations in the product is }(0=\text { zero, } 5=\text { very high) }\end{array}$ \\
\hline Multinational & MULTINAT & - Does the firm have foreign offices? Dummy variable ( 0 or 1$)$ \\
\hline
\end{tabular}


Table 2

Regression model for depth of international outsourcing $(N=189)$

\begin{tabular}{lccc}
\hline & Standardized beta & $t$ & Significance \\
\hline (Constant) & & -1.73 & .09 \\
Logged firm size & 0.22 & 3.33 & .00 \\
Extent of purchasing integration & 0.12 & 1.94 & .05 \\
Asset specificity & 0.14 & 2.10 & .04 \\
Volume uncertainty & -0.25 & -3.70 & .00 \\
Technological uncertainty & 0.03 & 0.38 & .71 \\
Product innovation & -0.02 & -0.35 & .73 \\
Multinational & 0.24 & 3.55 & .00 \\
\hline
\end{tabular}

$R^{2}=.277 ;$ Adj. $R^{2}=.249 ; F$ value $=9.902$.

more substantial volumes from abroad. This is in line with the basic assumption of scholars who study the inward-outward internationalization nexus (Welch and Luostarinen, 1993). This nexus indicates the intraorganizational knowledge and information transfer from the purchasing to the marketing department and vice versa. Mol et al. (2002), focusing on the types of firms and industries that engage in international outsourcing, found a positive influence of size on the depth of foreign outsourcing. When managing the scope of outsourcing, it will also be beneficial to be a large firm, inasmuch as large firms can cover more supply markets in their search function.

Multinationality was measured using a dichotomous dummy. Being part of a multinational company by definition implies that the company is also operating abroad. It can be assumed that these plants are more likely to source from more than one country, influencing both the depth and the scope of the company's foreign outsourcing. It is noteworthy that being a multinational does not necessarily imply that the firm is foreign-owned. Mol et al. (2002) found that multinationality is indeed positively related to depth of foreign outsourcing. We expect to replicate this finding for depth and for scope of foreign outsourcing.

\section{Analysis}

Multiple regression (OLS) and correlation analysis were applied to assess the proposed hypotheses. The regression model of the depth of international outsourcing is presented in

Table 3

Regression model for scope of international outsourcing $(N=189)$

\begin{tabular}{lcrc}
\hline & Standardized Beta & $t$ & Significance \\
\hline (Constant) & & -3.61 & .00 \\
Logged firm size & 0.26 & 3.81 & .00 \\
Extent of purchasing integration & 0.13 & 2.04 & .04 \\
Asset specificity & 0.15 & 2.27 & .02 \\
Volume uncertainty & -0.15 & -2.25 & .03 \\
Technological uncertainty & 0.20 & 2.74 & .01 \\
Product innovation & 0.16 & 2.30 & .02 \\
Multinational & 0.18 & 2.75 & .01 \\
\hline
\end{tabular}

$R^{2}=.281 ;$ Adj. $R^{2}=.253 ; F$ value $=10.094$. 
Table 4

Correlations with significance levels an $N$

\begin{tabular}{|c|c|c|c|c|c|c|c|c|c|c|c|c|c|c|}
\hline & SCOPE & DEPTH & Cell 1 & Cell 2 & Cell 3 & Cell 4 & LOGPURBU & PURINTEG & ASSETSPE & VOLUNCER & TECHUNCE & PRODINNO & MULTINAT & \\
\hline \multirow[t]{2}{*}{$\overline{\mathrm{SCOPE}}$} & 1.000 & & & & & & & & & & & & & \\
\hline & 199 & & & & & & & & & & & & & \\
\hline \multirow{3}{*}{ DEPTH } & .371 & 1.000 & & & & & & & & & & & & 3 \\
\hline & .000 & & & & & & & & & & & & & 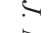 \\
\hline & 199 & 199 & & & & & & & & & & & & $\$$ \\
\hline \multirow[t]{3}{*}{ Cell 1} & -.605 & -.704 & 1.000 & & & & & & & & & & & $=$ \\
\hline & .000 & .000 & & & & & & & & & & & & 2 \\
\hline & 199 & 199 & 200 & & & & & & & & & & & 2 \\
\hline \multirow[t]{3}{*}{ Cell 2} & -.292 & .476 & -.381 & 1.000 & & & & & & & & & & 2 \\
\hline & .000 & .000 & .000 & & & & & & & & & & & 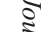 \\
\hline & 199 & 199 & 200 & 200 & & & & & & & & & & 3 \\
\hline \multirow[t]{3}{*}{ Cell 3} & .399 & -.262 & -.327 & -.222 & 1.000 & & & & & & & & & $\Sigma$ \\
\hline & .000 & .000 & .000 & .002 & & & & & & & & & & i \\
\hline & 199 & 199 & 200 & 200 & 200 & & & & & & & & & $\Xi$ \\
\hline \multirow[t]{3}{*}{ Cell 4} & .590 & .545 & -.456 & -.309 & -.265 & 1.000 & & & & & & & & อ \\
\hline & .000 & .000 & .000 & .000 & .000 & & & & & & & & & $\Xi$ \\
\hline & 199 & 199 & 200 & 200 & 200 & 200 & & & & & & & & $\stackrel{\nexists}{\approx}$ \\
\hline \multirow[t]{3}{*}{ LOGPURBU } & .353 & .326 & -.272 & -.012 & -.008 & .322 & 1.000 & & & & & & & $\Xi$ \\
\hline & .000 & .000 & .000 & .870 & .913 & .000 & . & & & & & & & 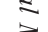 \\
\hline & 198 & 198 & 199 & 199 & 199 & 199 & 199 & & & & & & & $\lesssim$ \\
\hline \multirow[t]{3}{*}{ PURINTEG } & .132 & .061 & -.114 & -.054 & .076 & .101 & .013 & 1.000 & & & & & & $\Xi$ \\
\hline & .063 & .389 & .108 & .449 & .283 & .156 & .855 & & & & & & & के \\
\hline & 199 & 199 & 200 & 200 & 200 & 200 & 199 & 200 & & & & & & $\Xi$ \\
\hline \multirow[t]{3}{*}{ ASSETSPE } & .179 & .166 & -.161 & -.019 & .065 & .131 & .083 & -.043 & 1.000 & & & & & $\stackrel{8}{\approx}$ \\
\hline & .012 & .020 & .024 & .791 & .367 & .067 & .247 & .545 & & & & & & tr \\
\hline & 195 & 195 & 196 & 196 & 196 & 196 & 195 & 196 & 196 & & & & & \\
\hline \multirow[t]{3}{*}{ VOLUNCER } & -.151 & -.334 & .194 & -.098 & .115 & -.225 & -.170 & .076 & -.089 & 1.000 & & & & $\stackrel{ }{\curvearrowright}$ \\
\hline & .035 & .000 & .006 & .169 & .108 & .001 & .017 & .289 & .217 & & & & & $\nexists$ \\
\hline & 197 & 197 & 198 & 198 & 198 & 198 & 197 & 198 & 195 & 198 & & & & 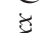 \\
\hline \multirow[t]{3}{*}{ TECHUNCE } & .200 & -.080 & -.101 & -.185 & .272 & .057 & .067 & .065 & -.012 & .313 & 1.000 & & & 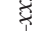 \\
\hline & .005 & .264 & .157 & .009 & .000 & .421 & .353 & .365 & .871 & .000 & . & & & $\frac{1}{x}$ \\
\hline & 197 & 197 & 198 & 198 & 198 & 198 & 197 & 198 & 195 & 198 & 198 & & & 8 \\
\hline \multirow[t]{3}{*}{ PRODINNO } & .229 & -.022 & -.020 & -.194 & .156 & .077 & .037 & .029 & .154 & .081 & .331 & 1.000 & & \\
\hline & .001 & .764 & .779 & .007 & .030 & .290 & .615 & .690 & .033 & .261 & .000 & . & & \\
\hline & 192 & 192 & 193 & 193 & 193 & 193 & 192 & 193 & 191 & 192 & 192 & 193 & & \\
\hline \multirow[t]{3}{*}{ MULTINAT } & .227 & .355 & -.240 & .150 & -.066 & .169 & .258 & -.086 & .071 & -.169 & -.139 & -.069 & 1.000 & \\
\hline & .001 & .000 & .001 & .033 & .354 & .017 & .000 & .223 & .326 & .017 & .051 & .340 & & \\
\hline & 199 & 199 & 200 & 200 & 200 & 200 & 199 & 200 & 196 & 198 & 198 & 193 & 200 & \\
\hline
\end{tabular}


Table 2. The model statistics, $R^{2}$ and $F$ value, are considered quite solid. Except for technological uncertainty and product innovation, all other contingency parameters turn out to be significant contributors to the model $(\alpha=5 \%)$.

Table 3 summarizes the regression model for the scope of international outsourcing. In contrast to the depth model, technological uncertainty and product innovation significantly contribute to the regression model of the scope of international outsourcing $(\alpha=5 \%)$.

Table 4 summarizes the results of the correlation analysis, including the correlations between the technological contingency parameters and four possible combinations of depth and scope of international outsourcing: low depth-low scope (Cell 1), high depthlow scope (Cell 2), low depth-high scope (Cell 3), and high depth-high scope (Cell 4). Most striking are the results on volume uncertainty, firm size, and multinationality when comparing Cell 1 and Cell 4, and on technological uncertainty and product innovation when comparing Cell 2 and Cell 3. Next, we discuss these results in more detail.

\section{Discussion}

The findings on product innovation partially support our hypotheses. Hypothesis 1a, stating that the level of product innovation has a negative impact on a firm's depth of foreign outsourcing, is not supported by the data. To the contrary, Hypothesis 1b, suggesting that increased product innovation increases the scope of international outsourcing, is clearly supported. We could not empirically confirm Dunning's (1993) alternative thesis of a U-shaped relation between technology level and depth of international outsourcing. Innovative tech firms do not outsource less abroad. They outsource differently. Apparently, in the context of increasing product innovation firms do not offset the costs related to an increasing scope of international outsourcing by reducing or increasing the depth of their international outsourcing activities. Consequentially, three options are open: (1) firms compensate for increased scope within the new and remote outsourcing ventures themselves, for instance, through contractual arrangements; (2) firms offset these increased costs in other activities not related to outsourcing; or (3) firms absorb these costs - mainly opportunity costs and increased risks - as they are inherently related to the innovative behavior of the firm - all in all, a firm's deliberate strategic choice.

The depth as well as the scope regression indicates a positive and significant relation between asset specificity and international outsourcing. This supports Hypotheses 2a and b. It appears that companies with high asset specificity outsource a substantial part of their goods and services from a variety of distant countries. A further rationale for this finding can be found in the economic evaluation of the sourcing costs compared to the alternative deployment possibilities of the financial means embedded in these specific assets. Assetspecific inputs are typically crucial to achieving competitive advantage, which contributes to the finding that firms go through the trouble of outsourcing internationally. Due to the limited size of the Netherlands, where the surveyed firms are located, more suppliers of asset-specific goods will by default be located outside the country.

Volume uncertainty is negatively related to both the scope and the depth of foreign outsourcing. This confirms Hypotheses $3 \mathrm{a}$ and $\mathrm{b}$. Indeed, when future volumes are uncertain and supply chain stability becomes low, international outsourcing becomes more 
costly and difficult (Levy, 1995). Obviously, this not only implies that outsourcing large volumes internationally is considered a dangerous strategy under the condition of volume uncertainty, but also that a concentrated (low scope) outsourcing strategy is preferred in an effort to increase the input volumes per supplier and, as such, aims to increase bargaining power.

Concerning the effect of technological uncertainty, the data partially support our hypotheses. No support was found for Hypothesis 3a that proposes a negative relation between technological uncertainty and depth of international outsourcing. Yet, the data were clear on Hypothesis $3 \mathrm{~b}$ : technological uncertainty is positively related to the scope of international outsourcing. In line with the findings on product innovation, technological uncertainty broadens the scope of international outsourcing without reducing its depth. To compensate for the costs of an increasing scope, the three aforementioned compensatory options are open.

Two conclusions can be drawn. First, the parallel findings on product innovation (internal parameter) and technological uncertainty (external parameter) hit the core of the relationship between technological volatility as a holistic contingency variable and the internationalization process of outsourcing. Technological volatility increases the scope of international outsourcing without reducing its depth. Second, the opposite effects of volume uncertainty and technological uncertainty on the scope of international outsourcing clarify why earlier studies did not find any significant result for an overall measure of environmental uncertainty.

The data illustrate that increasing integration between purchasing and other departments of a company has a positive effect on the degree and scope of international outsourcing, supporting Hypotheses $5 \mathrm{a}$ and $\mathrm{b}$ as well as earlier findings in the literature (e.g., Kotabe, 1992). On top of the technological contingency variables, the analyses provide interesting findings on the effect of multinationality and firm size. Both variables turn out to be positively related to the scope and depth of international outsourcing. The degree of international sourcing is positively related to outbound multinationality. This significant impact can be attributed to many factors. In their evolution from an ethnocentric to geocentric orientation, companies aim for a collaborative approach between headquarters and subsidiaries, thereby developing global standards, objectives, and reward systems (Perlmutter, 1995). Moreover, truly MNCs train and develop their (purchasing) staff everywhere, thereby building capabilities to exploit global (purchasing) advantages. These talented managers will then sense potential purchasing markets. Such companies also optimize their organization structure, which results, for instance, in a global matrix (Bartlett and Ghoshal, 1995).

With respect to firm size, larger companies may benefit from economies of scale. Therefore, they are better able to concentrate and coordinate their buying efforts of similar goods throughout the different plants (Faes et al., 2000). The larger firm and especially the multinational firm can also exploit economies of scope and learn from internal and external networks. Larger firms have more negotiation power, which compensates for increased costs of internationalization. As they also tend to have more personnel, specialization will occur more frequently. This makes the search for world-best sources more likely, thereby increasing both the scope and depth of international outsourcing. These findings support the basic assumption of scholars investigating the direct and indirect relationships between 
outward (product markets) and inward (factor markets) internationalization (e.g., Korhonen, 1999; Karlsen et al., 2003; Mol et al., 2002).

\section{A typology of international outsourcing}

On top of the effect of the contingency variables on the depth and scope separately, Table 4 summarizes their effects on the combination of scope and depth. This exercise allows us to develop a two-dimensional classification of the degree of international outsourcing in the context of technological and other contingency variables (Fig. 1). Sample splits on the basis of the average score on scope and depth allowed us to assign all observations to one of these four cells.

Cell 1 consists of 72 companies, characterized by a low depth and a low scope of international outsourcing. This group of nonmultinational firms is characterized by their small size, relatively limited asset specificity, and relatively high degree of volume uncertainty. Typically, Cell 1 harbors firms that are just starting to outsource on a more international scale and/or firms that are incapable of outsourcing abroad or are not forced to do so by market parameters. Firms in Cell 1 are labelled infant (Type 1) to reflect their limited focus on international outsourcing.

Cell 2 contains 41 companies, all characterized by a high depth and low scope in international outsourcing. As both technological uncertainty and product innovation correlate negatively with this type, it is expected that these firms do not operate in a technologically volatile environment. Most probably, for these firms, international outsourcing is a tactical instrument to minimize costs of supplies. Moreover, low scope and depth enhance bargaining power vis-à-vis a condensed cluster of nearby suppliers. In sum, these firms are not relying on the international arena for technological reasons but for efficiency reasons. The evolution of these firms towards a wider scope of outsourced

\begin{tabular}{|c|c|c|}
\hline \multirow{2}{*}{ low } & \multicolumn{2}{|c|}{ SCOPE } \\
\hline & $\begin{array}{l}\qquad \begin{array}{l}\text { Type 1: } \\
\text { Infant }\end{array} \\
\text { firm size }(-) \\
\text { asset specificity }(-) \\
\text { volume uncertainty }(+) \\
\text { multinational }(-)\end{array}$ & $\begin{array}{l}\text { Type 3: } \\
\text { Opportunity taker } \\
\text { technological uncertainty }(+) \\
\text { product innovation }(+)\end{array}$ \\
\hline high & $\begin{array}{l}\text { Type 2: } \\
\text { Bounded player } \\
\text { technological uncertainty (-) } \\
\text { product innovation(-) }\end{array}$ & $\begin{array}{l}\qquad \begin{array}{l}\text { Type 4: } \\
\text { Mature globalists }\end{array} \\
\text { firm size }(+) \\
\text { volume uncertainty }(-) \\
\text { multinational }(+)\end{array}$ \\
\hline
\end{tabular}

Fig. 1. A typology of international outsourcing with underlying dimensions. 
activities is bounded by their cost-minimizing strategies. Consequentially, we label this type of firms bounded players (Type 2).

The 32 companies with low depth but high scope are incorporated in Cell 3. The characteristics are opposite to those of bounded players (Cell 2). A positive correlation with both product innovation and technological uncertainty indicates that these firms operate in a technological volatile environment. For firms in Cell 3, the driver of outsourcing internationalization is innovation-related and typically counters the costs that are associated with sourcing small quantities from numerous and remote countries. We call this type of company an opportunity taker (Type 3).

Cell 4 consists of 54 companies with a high score for both depth and scope of foreign outsourcing. This type comprises the larger multinational firms, which are typically confronted with volume uncertainty. We label these firms mature globalists (Type 4), as it is assumed that they represent the most advanced category of international outsourcing companies, driven in their internationalization process by both cost and innovation drivers.

\section{Towards a dynamic perspective on international expansion of outsourcing}

On the basis of Table 4 and Fig. 1, a dynamic perspective on the international expansion of outsourcing can be developed. It may be expected that infants depart from their cell when technological volatility increases (towards Type 3) or financial criteria become stricter (towards Type 2). Eventually, Types 1, 2, and 3 may grow into experienced and mature outsourcing globalists (Type 4) when they have matured in their original position through experiential learning. As such, the typology presented in Fig. 1 can be considered as a dynamic perspective on possible expansion paths of international outsourcing.

Given the contingency factors related to each of these types, the typology might even have predictive power over the international expansion path of outsourcing firms. More particularly, it is expected that less innovative firms that operate in a technological nonvolatile environment will experience a convex, concentrated expansion path (Type $1 \rightarrow$ Type $2 \rightarrow$ Type 4 ), whereas more innovative firms operating in a technological volatile environment will experience a concave, diversified expansion path (Type $1 \rightarrow$ Type $3 \rightarrow$ Type 4 ) [in analogy to Ayal and Zif, 1979]. In fact, the former category seeks to exploit international opportunities to mainly reach lower costs. They build a supply network of low-cost outsourcing partners, and because scale economies count, the number of international sources is supposed to be rather limited. The latter category focuses on reaching competitive advantages through the tapping of innovative sourcing opportunities. If successful, they will use a wide variety of innovative suppliers with whom they reach close cooperation. Furthermore, it is expected that a concentrated expansion path (via Type 2) will less likely lead to maturity (Type 4).

Given the 'complexity costs' of coordinating a wide scope of suppliers, an increasing scope of international outsourcing conflicts with the fundamental cost driver of Type 2 firms. The diversification path is alleged to lead to faster internationalization. Uncertainty and volatility of technology imply a frequent change in specifications, whereby finding market opportunities in terms of new materials, new suppliers, and better quality becomes essential, boosting the search for world-best suppliers. Whereas the evolution from Type 2 
to Type 4 is hindered by cost implications, the progression from Type 3 towards Type 4 does not have this barrier. Outsourcing more when dealing with technologically uncertain and innovative products suggests a tendency towards some degree of standardization and maturity of the produced goods, whereby larger quantities are needed.

This dynamic perspective is not normative in the sense that (1) not all companies follow these patterns, and (2) Cell 4 is not a natural and optimal endpoint for global sourcing in all cases. Contingency factors beyond the aforementioned technological perspective may constrain the internationalization process of outsourcing or may result in Types 1, 2, or 3 being optimal modes. While the explanatory logic of described dynamism is most plausible, it needs empirical support and corroboration.

\section{Limitations, conclusions, and suggestions for future research}

We acknowledge that the current paper has a number of shortcomings. Depth and scope are currently measured by means of one criterion each. This could be expanded, for instance, by incorporating the number of foreign suppliers to determine scope. Similarly, some of the independent measures were found to be not fully reliable and might need improvement. Moreover, there may be additional factors to discern when explaining foreign outsourcing, which could further enhance the explanatory value of the model. One might, for example, take into account the history of the firm as one important predictor of its current international outsourcing pattern. Merged firms produce patterns that can strongly deviate from their independent peers. Of course there are also inherent limitations attached to single country research designs. It may well be that these findings are specific for the case of the Netherlands, although no such indications were found beyond the fact that size and scope of the local supply base are limited. Replication elsewhere would be useful. Furthermore, a more extensive investigation of the characteristics of the various types deserves more attention in the future. Another interesting and important avenue for future research, unfortunately beyond the scope of the current paper, is how scope and depth of international outsourcing influence the performance of firms and how this relation itself may be modified by other variables. For instance, it may well be the case that hightech firms not only use a high scope of international outsourcing but are also better off doing so. For now, however, foreign outsourcing has been identified as a multidimensional phenomenon with several mutually supportive explanations.

In sum, international outsourcing was characterized by two dimensions: depth and scope. A technological contingency perspective on these two dimensions produced a reasonably sound yet discriminating perspective. The scope of international outsourcing turned out to be positively related to technological uncertainty and product innovation, whereas these variables did not load significantly on depth of international outsourcing. In addition, asset specificity is positively related to scope and depth, while volume uncertainty has a negative impact. From a more dynamic perspective, these findings are promising inasmuch as they can predict the international expansion of outsourcing. However, this has not been corroborated empirically. It was proposed that a more technologically intense environment induces a more diversified internationalization path, whereas a less technologically intense environment induces a more concentrated path. Managers ought to be aware that product 
factors are key determinants of sourcing strategy and that expansion paths can go through either the innovative trajectory or the cost-minimizing approach.

Given the increasing strategic and economic importance of outsourcing in supply chains of globally operating firms, it would be wise to increase academic efforts on global outsourcing. It is of utmost importance to avoid empirical and conceptual simplification of the core object. To assure the former, international outsourcing should be studied in relation to relevant contextual parameters. The latter is guaranteed when outsourcing studies apply theories currently driving academic progress in economics and business administration.

\section{References}

Andersen, O., Buvik, A., 2001. Inter-firm co-ordination: international versus domestic buyer-seller relationships. Omega 29 (2), 207-219.

Ayal, I., Zif, J., 1979. Market expansion in multinational marketing. J. Mark. 43 (Spring), 84-94.

Bailey, W., Masson, R., Raeside, R., 2002. Outsourcing in Edinburgh and the Lothians. Eur. J. Purch. Supply Manag. 8, 83-95.

Bartlett, C.A., Ghoshal, S., 1995. Transnational management. Text, Cases, and Readings in Crossborder Management. Irwin, Boston.

Birou, L.M., Fawcett, S.E., 1993. International purchasing benefits, requirements and challenges. J. Purch. Mater. Manage. 29 (2), 28-37.

Bryce, D.J., Useem, M., 1998. The impact of corporate outsourcing on company value. Eur. Manag. J. 16 (6), 635-643.

Buckley, P.J., 2002. Is the international business research agenda running out of steam? J. Int. Bus. Stud. 33 (2), 365-373.

Carter, P.L., Carter, J.R., Monczka, R.M., Slaight, T.H., Swan, A.J., 2000. The future of purchasing and supply: a ten-year forecast. J. Supply Chain Manag. 36 (1), 14-26.

Cavusgil, S.T., 1980. On the internationalization process of firms. Eur. Res. 8 (6), 273-281.

Deavers, K.L., 1997. Outsourcing: a corporate competitiveness strategy, not a search for low wages. J. Labor Res. 18 (4), 503-519.

Dillman, D.A., 1978. Mail and Telephone Surveys: The Total Design Method. Wiley, New York.

Doz, Y., Santos, J., Williamson, P., 2000. From Global to Metanational: How Companies Win in the Knowledge Economy. Harvard Business School Press, Boston.

Dubois, A., 1998. Organising Industrial Activities Across Firm Boundaries. Routledge, London.

Dunning, J.H., 1993. Multinational Enterprises and the Global Economy. Addison-Wesley, Wokingham.

Eisenhardt, K.M., 1989. Making fast strategic decisions in high-velocity environments. Acad. Manage. J. 14 (4), 532-550.

Eisenhardt, K.M., Tabrizi, B.N., 1995. Accelerating adaptive processes: product innovation in the global computer industry. Adm. Sci. Q. 40 (March), 84-110.

Faes, W., Matthyssens, P., Vandenbempt, K., 2000. The pursuit of global purchasing synergy. Ind. Mark. Manage. 29 (6), 539-553.

Ford, D., 1998. Managing Business Relationships. Wiley, Chichester.

Grisprud, G., 1990. The determinants of export decisions and attitudes to a distant market: Norwegian fishery exports to Japan. J. Int. Bus. Stud. 21 (3), 469-486.

Hagedoorn, J., Narula, R., 1996. Choosing organizational modes of strategic technology partnering: international and sectoral differences. J. Int. Bus. Stud. 27, 265-284. 
Hallén, L., Wiedersheim-Paul, F., 1989. The evolution of psychic distance in international business relationships. In: Haag, I., Wiedersheim-Paul, F. (Eds.), Between Market and Hierarchy. University of Uppsala, Sweden, pp. 15-27.

Johanson, J., Vahlne, J.-E., 1977. The internationalization process of the firm-a model of knowledge development and increasing foreign commitment. J. Int. Bus. Stud. 8 (2), 23-32.

Karlsen, T., Silseth, P.R., Benito, G.R.G., Welch, L.S., 2003. Knowledge, internationalization of the firm, and inward-outward connections. Ind. Mark. Manage. 32 (5), 385-396.

Korhonen, H., 1999. Inward-outward internationalization of small and medium enterprises. HeSE Print, Helsinki.

Kotabe, M., 1992. Global Outsourcing Strategy: R and D, Manufacturing, and Marketing Interfaces. Quorum Books, New York.

Kotabe, M., 1998. Efficiency vs. effectiveness orientation of global outsourcing strategy: a comparison of U.S. and Japanese multinational companies. Acad. Manage. Exec. 12 (4), 107-119.

Kotabe, M., Murray, J.Y., 1996. Determinants of intra-firm outsourcing and market performance. Int. Bus. Rev. 5 (2), 121-135.

Kotabe, M., Omura, G.S., 1989. Outsourcing strategies of European and Japanese multinationals: a comparison. J. Int. Bus. Stud. 20 (1), 113-130.

Kotabe, M., Murray, J.Y., Javalgi, R.G., 1998. Global outsourcing of services and market performance: an empirical investigation. J. Int. Mark. 6 (4), 10-31.

Lawrence, P.R., Lorsch, J.W., 1967. Organisation and Environment. Irwin, Homewood, IL.

Leonidou, L.C., Katsikeas, C.S., 1996. The export development process: an integrative review of empirical models. J. Int. Bus. Stud. 27 (3), 517-551.

Levy, D.L., 1995. International outsourcing and supply chain stability. J. Int. Bus. Stud. 26 (2), $343-360$.

March, J.G., Simon, H.A., 1958. Organizations. Wiley, New York.

Mol, M.J., van Tulder, R.J.M., Beije, P.R., 2002. Global outsourcing: fad or fact? Erasmus Research Institute of Management. Working Paper 2002-55-ORG, Rotterdam.

Monczka, R.M., Trent, R.J., 1992. Worldwide outsourcing: assessment and execution. Int. J. Purch. Mater. Manage. 28 (4), 9-18.

Monczka, R.M., Trent, R.J., Handfield, R.B., 2002. Purchasing and Supply Chain Management. South-Western, Cincinnati.

Murray, J.Y., 2001. Strategic alliance-based global sourcing strategy for competitive advantage: a conceptual framework and research propositions. J. Int. Mark. 9 (4), 30-58.

Murray, J.Y., Kotabe, M., Wildt, A.R., 1995. Strategic and financial implications of global outsourcing strategy: a contingency analysis. J. Int. Bus. Stud. 26 (1), 181-202.

Narasimhan, R., Carter, J.R., 1990. Organisation, communication and co-ordination of international outsourcing. Int. Mark. Rev. 7 (2), 6-20.

Olusoga, S.A., 1993. Market concentration versus market diversification and internationalization: implications for MNE performance. Int. Mark. Rev. 10 (2), 40-59.

Perlmutter, H.V., 1995. The tortuous evolution of the multinational corporation. In: Bartlett, C.A., Ghoshal, S. (Eds.), Transnational Management: Text, Cases, and Readings in Cross-border Management. Irwin, Boston, pp. 92-101.

Petersen, K.J., Frayer, D.J., Scannell, T.V., 2000. An empirical investigation of global outsourcing strategy effectiveness. J. Supply Chain Manag. 36 (2), 29-38.

Prescott, J.E., 1986. Environments as moderators of the relationship between strategy and performance. Acad. Manage. J. 29, 329-346.

Reid, S.D., 1984. Market expansion and firm internationalization. In: Kaynak, E. (Ed.), International Marketing Management. Praeger, New York, pp. 18-38.

Servais, P., Møller Jensen, J., 2001. The internationalization of industrial purchasing: the example of 
small Danish manufacturers. In: Axinn, C.N., Matthyssens, P. (Eds.), Reassessing the Internationalization of the Firm, Advances in International Marketing, vol. 11. JAI, Elsevier Science, Amsterdam, pp. 227-254.

Steensma, H.K., Corley, K.G., 2000. On the performance of technology-sourcing partnerships: the interaction between partner interdependence and technology attributes. Acad. Manage. J. 43 (6), $1045-1067$.

Steensma, H.K., Fairbank, J.F., 1999. Internalizing external technology: a model of governance mode choice and an empirical assessment. J. High Technol. Managem. Res. 10 (1), 1-35.

Stöttinger, B., Schegelmilch, B.B., 1998. Explaining export development through psychic distance: enlightening or elusive? Int. Mark. Rev. 15 (5), 357-372.

Sullivan, D., 1994. Measuring the degree of internationalization of a firm. J. Int. Bus. Stud. 25 (2), $325-342$.

Sullivan, D., 1996. Measuring the degree of internationalization of a firm: a reply. J. Int. Bus. Stud. 27, 179-192.

Swamidass, P.M., Kotabe, M., 1993. Component outsourcing strategies of multinationals: an empirical study of European and Japanese multinationals. J. Int. Bus. Stud. 24 (1), 81-99.

Trent, R.J., Monczka, R.M., 1998. Purchasing and supply management: trends and changes throughout the 1990s. Int. J. Purch. Mater. Manage. 34 (4), $2-11$.

Walker, G., Weber, D., 1984. A transaction cost approach to make-buy decisions. Adm. Sci. Q. 36 (1), 373-391.

Welch, L.S., Luostarinen, R.K., 1988. Internationalization: evolution of a concept. J. Gen. Manage. 14 (2), 34-55.

Welch, L.S., Luostarinen, R.K., 1993. Inward-outward connections in internationalization. J. Int. Mark. 1 (1), 44-56. 